\title{
Socio Cultural Reactions Before the Nationalitation of Dutch Railroad in Indonesia 1945-1958
}

\author{
Waskito Widi Wardojo*, Singgih Tri Sulistiyono, Endang Susilowati, Yety \\ Rochwulaningsih \\ Department History, Faculty of Humanities, Diponegoro University, Semarang - Indonesia
}

\begin{abstract}
The issue of the nationalization of Dutch companies (railroad), which strengthened in the early 1950s, had caused some concern among Dutch companies. The issue was rolled by leftists who were disappointed with some of the results of the Round Table Conference (RTC) in December 1949. There was a phenomenon of xenophobia among natives of something that smelled of foreign (Western) so that the government policies that emerged were rooted in this matter, starting from the Benteng program and the nationalization of the company foreign. This paper aims to parse the anti-foreign phenomenon before nationalization by emphasizing the socio-cultural aspects. If the political process is carried out by the state political elite, then the social process is carried out by other elements of society such as trade unions in the form of boycotts, strikes and demonstrations. While cultural action is carried out by elements of society such as artists and humanists who carry out a variety of artistic actions such as murals, propaganda graffiti, advertisements in the mass media or images that burn the spirit of warriors on the walls in the city area. Particularly among railways, various socio-cultural activities were carried out by the Djawatan Kereta Api (DKA) in the 1950s. This research uses historical research methods based on primary sources traced from archival institutions and libraries. Research results show that the phenomenon of xenophobia that occurred in the decade of the 50s is part of the national socio-political criticism expressed through various forms of social culture.
\end{abstract}

Keyword: xenophobia, murals, propaganda graffiti, .

* Corresponding author: widiwardoyo@gmail.com 


\section{Introduction}

The issue of the nationalization of Dutch companies, which had strengthened in the early 1950s, had troubled some Dutch companies. The issue was revolved by the left groups who did not approve part of the results of the RTC in December 1949. The left group led by the Indonesian Communist Party (PKI) prefers a radical strategy to expel Western elements after Indonesia's sovereignty [1].

Some people call the phenomenon of xenophobia on everything that smells foreign (Western). Ben Andersen said that in the post-independence period until the early 1950s, the country almost disappeared given the number of popular uprisings [2]. The Indonesian state through the military was only able to consolidate its power and position in the 1950s. Amid the turmoil in the various regions, and the internal consolidation of the railways after the establishment of the railroad department (1950). Crime rates against railroad passengers and labor demonstrations and protests against railroad conditions have risen [3]. In the midst of the railway conditions and the nationalization issue that heats up, there are a variety of arts and cultural actions carried out by artists and train workers. At that time the workers and railroad workers who were members of the railroad trade union played an important role. This paper focuses on socio-cultural activities that escaped the attention of other researchers, such as Tod Jones [4], Baskoro Suryo Banindro [5], and Goenawan Mohammad [6].

\section{Method}

This research method is based on historical research based on the heuristic stage in the form of tracking primary sources. The primary source is in the form of contemporary documents and newspapers stored in the National Archives of the Republic of Indonesia in Jakarta (ANRI) and the Jakarta National Library. After various data have been collected from the two institutions, the next step is to critique the content as well as the source material. After knowing the validity of the source, an equally important step is to interpret the data source. By interpreting, it is hoped that the facts will be arranged chronologically so that a research report is obtained that is systematic and easily understood by the reader [7].

\section{Results and Discussion}

The state situation in the 1950s described by Ben Andersen, almost disappeared. Because the focus of the country at that time was to suppress various regional uprisings ranging from the PKI Madiun uprising in 1948, PRRI / Permesta in West Sumatra, Darul Islam Kartosuwiryo in West Java, Kahar Muzakar in South Sulawesi, and so on. In the midst of this situation, the condition of the Indonesian railways was very poor. The length of rails in the Dutch East Indies in 1939 was 6,702 kilometers. The transport fleet consisted of 1,263 locomotives, 3,553 passenger trains, and 27,201 freight cars. During the Japanese occupation, $473 \mathrm{~km}$ of railroad demolition took place. While the railroad that was built was only $83 \mathrm{~km}$ between Bayah-Cikara (Banten) and $220 \mathrm{~km}$ between Muaro-Pekanbaru. The Muaro-Pekanbaru route was worked on for 15 months by around 27,500 workers, 25 thousand of whom were romusha. In 1945 the length of the railroad tracks was reduced to $5,910 \mathrm{~km}$, a reduction of around $901 \mathrm{~km}$ was estimated to be demolished during the Japanese occupation and transported to Burma as a Japanese colony at that time [8]. 
The condition of the railroad infrastructure is a challenge for the newly formed Djawatan Kereta Api (DKA), while the drive for nationalization of the Dutch private railroad company is increasing. DKA at that time was a combination of the Republic of Indonesia Railroad Department (DKARI) and Verenidge Spoorwegbedrijft (VS) as a joint venture company owned by the Dutch private sector

\subsection{Various Forms of Action}

Various demands of railroad workers protesting against various policies such as increased crime, labor protection, and encouragement of nationalization surfaced [9]. In such conditions, the laborers were railroad workers who were quite professional and politically literate at the time. As one of the social groups who have a strong awareness of class differences and identity and identity, on the one hand, workers have a great ability to build solidarity between themselves in order to survive. While on the other hand, this power will be very easily interpreted by those outside labor as both a threat and a potential.

The history of the labor movement that began with the railroad workers in Semarang apparently still carried over until the end of the Japanese occupation to the nationalization of the Dutch railway [10]. In early 1945 the railroad workers fought against Japan. For example, railroad workers from the Western and Eastern Exploitation Stations spread news of the war situation in Europe and Asia and planned to sabotage trains carrying Japanese troops. This includes the Krengseng event. The workers and youth then formed a trade union that was incorporated in the Railway Youth Force (AMKA) [11]. AMKA at that time consisted of train train candidates who also seized Japanese weapons and seized the train station from August to September 1945. Assisted by youth troops and postal and telecommunications workers, the takeover of the station was carried out before the Allies arrived.

At the time of the station's takeover, young people from various bodies of struggle carried out their doodles. The train was targeted by youth scribbles, as revealed by Suromo, a member of the Indonesian Photographers Association (Persagi).

At the time of the revolution of August 17, 1945, I was the one who scribbled on the train at Manggarai station was completely crossed out. The one who crossed out was not just me, wow, a lot of boys. All. I took part in crossing out in English what is "freedom", moreover it continues to be "Hands off", well, as far as I know. Both railroad cars and locomotives work as canvas to work either in the form of paintings of dove a la Pablo Picasso, or chains detached from the hands of free humans [12]. In the illustration as below:

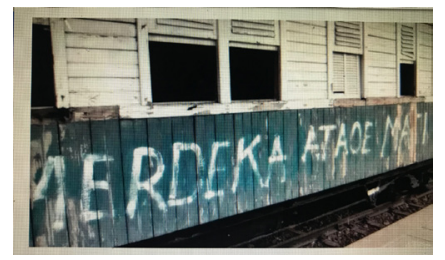

Fig. 1. Historic carriage. One of the carriages that was crossed out by youths and railroad workers. Currently this train car is stored in the Jakarta Beautiful Taman Mini Transportation Museum Kompas.com Repro

In the carriage, the words "Merdeka Ataoe Mati" appear, have become its own street art that is useful as a container for people's aspirations through paintings with nuances of 
criticism, event information, as well as a unifying means of conscience between artists and the public. The carriage was a class III long-staggered wooden passenger train series CL5329 that served during the independence war in 1945. The 1930 struggle struggle was used to transport fighters and combat victims to safe areas in the interior of the Republic of Indonesia, as well as a means to smuggle weapons from enemy areas inland. The word merdeka or death on the train body is one of the slogans that aims to ignite the spirit of the people's struggle in facing terror carried out by the Dutch military. These slogans are found in various places such as walls, buildings, train stations and on the passenger train body that will enter the Jakarta area

In addition to the crossing out, there are also various artists' actions in the form of posters containing propaganda and kindling. That is why the history of Indonesia's independence struggle cannot be separated from the role of murals, posters and graffiti as a medium to spread the spirit of the people's struggle against the Dutch invaders. Although at that time the tools used to make murals, graffiti, and posters were still very simple but did not prevent the fighters from spreading the spirit of the struggle against the Dutch invaders.

As shown in the picture:

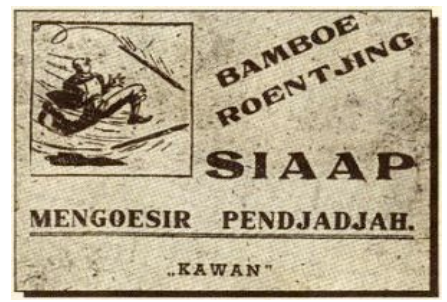

Fig. 2. Poster Against Invaders Source: https: //nurdayat.wordpress.com

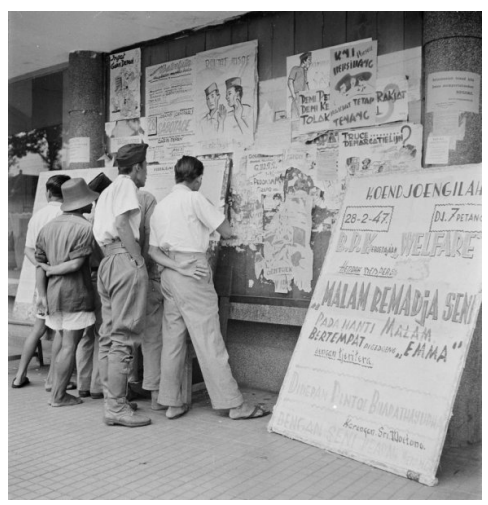

Fig. 3. People reading various posters mounted on the wall. The environment has been taken care of. (www.mobgenic.com)

\subsection{Cultural Action}

Amid the consolidation and improvement of railroad infrastructure, DKA turned out to be carrying out a series of very interesting cultural activities. DKA collaborates with the Jakarta Development Foundation to create a cultural movement. The movement is the manufacture of two bookcases carriages that run through certain lines. In each destination 
determined, film screenings were interspersed with discussions. The activity was opened by the late Siti Rahmiati Hatta and the train started running on September 26, 1951 [13].

The two DKA carriages specially arranged for that in a short time will begin the journey to the smallest places, which can be reached by railroad. In a car, a permanent exhibition will be held, with a guide car placed in the second car. The book carriage consists of two carriages so that the Development Foundation is grateful for the collaboration of the Jakarta Railroad Department in Bandung, which was handed over and later at the DKA workshop in Manggarai built according to the design of Mr. Awuy, the interior architect; the biggest car is used as a book car, the smallest one is for the opportunity to accommodate accompanying employees, namely Mr Aulia, Ishak and A. Djajusman.

The large car (made from used class 2 cars) was converted into a specially-managed and attractive bookstore that could accommodate 10-15 thousand copies of the 800 books that could be carried. The carriages are equipped with air holes and cooling installations. The idea of this book train arises from an awareness of the need for good books, but is only centered in big cities, so it is less supportive for the progress of the people. The Development Foundation which has branches in Yogyakarta and Solo hopes to fill this gap.

This train departed on September 26, 1951 in the morning, route from Jakarta to Banten, then returned to Jakarta to then begin the journey through West Java, Central Java and East Java. Every month six months for several days stopped. In places visited by the train, in the evening the lighting film was held by the State Film Company, Stichting Cult. Samenwerking, USIS and the British Information Center UK, are exhibited both publicly and specifically for school students. Included in the activity was the distribution of 800 free book titles by the Development Foundation.

Looking at the railroad book program above shows that DKA was trying to take action that should have been taken, not just transportation of economic transportation. This illustrates that trains are ambassadors of extraordinary educational facilities in situations of economic limitations and security uncertainty in Indonesia.

\section{Conclusion}

Various dynamics of the people ahead of the nationalization of the Dutch railroad company in 1958 are a reflection of nationalism. Every political policy adopted by the political elite at that time had a broad dimension to other aspects, both social and cultural. These various people's actions represented a desire to be free from colonialism. Because there seems to be xenophobia on all things related to the Netherlands which are assumed to be Western. After the nationalization of 10 private Dutch railroad companies was carried out, the railroad problem was not solved. In fact, this policy is a momentum for the future sustainability of the next train.

\section{Acknowledgement}

In this change, the writer would like to say thanks to DIRSIMLITABMAS for its support and DPRM funding for writer's doctoral funding (2020-2021). This manuscript is one of parts in writer's doctoral funding. The writer also would like to thank to Prof.Dr. Singgih Tri Sulistiyono, M.Hum. as disertation promoter and Dr. Endang Susilowati, M.A. as Co Promoter, and also Prof.Dr. Yety Rochwulaningsih, M.Si. for her support in reaching for this doctoral funding 


\section{References}

1. Bondan Kanumuyoso, Nasionalisasi Perusahaan Belanda, (2001).

2. Ben Anderson, "Old state, new society: Indonesia's New Order in Communication under the New Order, 1990.Wrahatnala, Bondet, Kebertahanan Kentrung Dalam Kehidupan Masyarakat Jepara (2017)

3. "Veiligheidsmaartregelen", Algemeneen Indisch Daglad, November, 301950

4. Tod Jones, Kebudayaan dan Kekuasaan di Indonesia, 2015

5. Baskoro Suryo Banindro, "Daya Gagas Poster Dalam Pergerakan dan Kebebasan Revolusi Indonesia 1945- 1965”. Jurnal Seni Rupa dan Desain, Vol. 21 Number 1, 2018.

6. Goenawan Mohammad, Seni, Politik, Pembebasan, (2018)

7. Imam Subarkah, Sekilas 125 Tahun Kereta Api Kita 1867-1992, (1992)

8. "Werkers bepalen zelf hun uren", Algemeen Indisch Dagblad, Mei 25,1951

9. Erwiza Erman dan Ratna Saptari (ed), Dekolonisasi Buruh Kota dan Pembentukan Bangsa, (2013).

10. John Ingleson, Buruh, Serikat dan Politik, (2015)

11. Razief, "Buruh Kereta Api dan Komunitas Buruh Manggarai", Dekolonisasi Buruh Kota dan Pembentukan Bangsa, (2013).

12. Razief, "Buruh Kereta Api dan Komunitas Buruh Manggarai", Dekolonisasi Buruh Kota dan Pembentukan Bangsa, (2013).

13. "De boekentrein van Pembangunan", De nieuwsgier, September 25, 1951 